Kirja-arvio

\title{
Etnografisia pastisseja saunakokemuksista
}

\author{
Seesmeri, Laura. 2018. Sauno itsellesi menneisyys: Kehollisuus osana muisteltua \\ ja esitettyä kokemusta. Joensuu: Suomen Kansantietouden Tutkijain Seura.
} 292 sivua.

Nika Potinkara

$\mathrm{S}$ auna ja saunominen on pitkään nähty yhtenä keskeisenä suomalaisuutta määrittelevänä kulttuuripiirteenä. Kiinnostuksesta saunomisperinteeseen kertoo esimerkiksi se, että perinnettä on viime vuosikymmenien aikana kartoitettu useilla keruilla ja kyselyillä. Sitä on myös haluttu tietoisesti ylläpitää: yli 80 vuotta toiminut Suomen Saunaseura pyrkii vaalimaan perinteisiä saunomistapoja ja jakamaan tietoa suomalaisesta saunasta, ja tällä hetkellä on vireillä hanke saunomisen nimeämiseksi Unescon aineettoman kulttuuriperinnön luetteloon.

Tutkimuksen kentällä sauna on ollut niin kansatieteellisen kuin lääketieteellisenkin kiinnostuksen kohteena. Saunan kautta on jopa pyritty selittämään koko suomalaista kulttuuria (Edelsward 1991); Ruotsissa saunaa taas on tarkasteltu osana hygieniaa painottavaa ideologiaa, jonka tavoit-

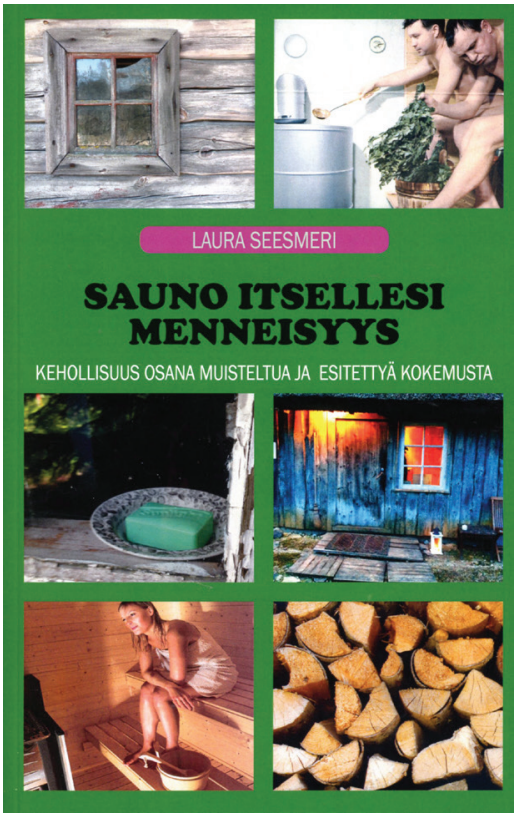
teena oli kansakunnan vahvistaminen (Frykman 2004; Wiell 2018). Laura Seesmeren väitöstutkimus Sauno itsellesi menneisyys: Kehollisuus osana muisteltua ja esitettyä kokemusta (2018) lähestyy saunaa varsin erilaisesta näkökulmasta. Saunomisen käytännöllisten, sosiaalisten ja moraalisten ulottuvuuksien sijaan keskiössä on saunojan henkilökohtainen kehollinen kokemus.

Seesmeri paikantaa tutkimuksensa niin maisemantutkimukseen, kokemuksentutkimukseen, muistitietotutkimukseen kuin aistimelliseen etnografiaankin. Hän kysyy, miten menneisyyden ja tulevaisuuden sekä yksilöllisyyden ja yhteisöllisyyden jännitteet tulevat esiin saunakokemuksissa, miten kokemukset kokoavat erilaisia aikatasoja ja sulauttavat yhteen erilaisia dikotomioita, millainen tunnekartta saunasta rakentuu ja mikä on esteettisyyden ja affektiivisuuden rooli kokemuksessa sekä miten kokemuksellisuutta representoidaan. Tutkimuksen kolmeksi pääteemaksi nousevat maisema tai paikka, kehollisuus ja siihen liittyvä aistimellisuus sekä ajallisuus tai menneisyys. Koko tutkimusta määrittää kokemuksellisuus, ja symbolista kokemuksellista kehystä tavoittelee tutkimuksen jäsennyskin: 
väitöskirjan johdanto-osuus on nimetty "Saunapolulle" ja tuloksia esitetään kokoavasti luvussa "Löylyjen jälkeen".

\section{Keruuvastaukset ja mainokset saunomiskokemuksen representaatioina}

Väitöstutkimuksen asetelma on poikkeuksellisen kiinnostava, sillä tutkimuksen empiiriseen aineistoon kuuluu sekä saunomista käsitteleviä kokemuskertomuksia että kiuasmainoksia. Vaikka näitä aineistotyyppejä saattaisi ensikuulemalta pitää jopa yhteismitattomina, Seesmeri osoittaa, että niistä voidaan etsiä vastauksia samoihin kysymyksiin. Molemmissa aineistoissa on kyse saunomiskokemuksen representoimisesta: kertojat kuvaavat omia saunomismuistojaan, mainokset taas esittävät saunaa herättääkseen muistoja, mielikuvia ja tunteita. Pyrkiessään vetoamaan kuluttajiin mainokset käyttävät hyväkseen tunnistettavia kokemuksia ja arvoja, joten ne kertovat saunomiseen liittyvistä kulttuurisesti jaetuista merkityksistä. Nämä jaetut merkitykset kytkeytyvät myös henkilökohtaista saunomiskokemusta kuvaaviin kertomuksiin, sillä kulttuuri vaikuttaa kokemukseen ja siihen, miten sitä kerronnassa representoidaan.

Kokemuskertomuksia sisältävä muistitietoaineisto on peräisin kahdesta Suomalaisen Kirjallisuuden Seuran kansanrunousarkiston organisoimasta keruusta, joista ensimmäinen toteutettiin vuonna 1992 ja toinen vuosina 2010-2011. Vanhempi keruu käsitteli useita saunomiseen liittyviä teemoja mutta painotti saunan terveysvaikutuksia, uudempi keruu taas keskittyi sukupuolinäkökulmaan. Seesmeren kiinnostuksen kohteena oleva kehollinen kokemuksellisuus ei ollut kummankaan keruun pääsisältöä, mutta tutkijan mukaan se tulee aineistoista esiin joka tapauksessa. Molemmista keruuaineistoista tekijä on poiminut joukon eripituisia katkelmia, joissa "kokemus konkretisoituu muisteltuna tai arvotettuna kehollisena paikkaan sidottuna toimena" ja "kokemuksen hetkellisyys liittyy muistettuun" (s. 43). Nämä poiminnat muodostavat tutkimuksen sitaattiaineiston, josta tutkija tulkitsee saunan kokemuksellisuutta. Niiden rinnalla käytetään pääasiassa esitteistä koostuvaa mainosaineistoa, joka ulottuu vuodesta 1959 viime vuosiin asti. Aineistoon kuuluu 90 kiuasmainosta, yksi brändimanuaali sekä yksi kiuaskivien mainosfilmi.

Tutkimusaineistot on analyysin yhteydessä järjestetty temaattisesti. Analyysimenetelmänä on hermeneuttinen lähiluku, jonka käytännön kuvaus jää tutkimuksen metodeja käsittelevässä luvussa melko niukaksi. Empiirisen osuuden analyysiesimerkit ja liitteessä esitetty esimerkki aineistokokonaisuuden taulukoinnista kuitenkin havainnollistavat aineiston käsittelyä.

\section{Maisema, kehollisuus ja menneisyys}

Tutkimustuloksia esitetään kahdessa laajassa analyysiluvussa, joista ensimmäinen käsittelee kokemuskerrontaa ja toinen mainosten representoimaa saunaa. Analyysi etenee lähinnä valittujen teemojen mukaan jäsennettynä. Molempien lukujen lopussa aineistoa kuitenkin esitetään myös tapausesimerkkien kautta: Seesmeri analysoi kolmea kokemuskertomusta ja kolmea mainosta kokonaisuuksina, mikä avaakin aineistoa ja tutkijan siitä tekemiä tulkintoja uudella tavalla.

Analyysiluvut rinnastuvat pitkältitoisiinsa, koska molemmissakäydäänläpisamoja maiseman, kehollisuuden ja ajallisuuden teemoja. Pieniä erojakin kuitenkin on. Kokemuskerronnassa 
metaforien käyttäminen ja runomuotoiset vastaukset saavat omat alalukunsa, mainosaineiston analyysiin taas sisältyy ajallinen ulottuvuus, joka kokemuskerronnassa ei samalla tavalla tule esiin. Keruuvastauksetkin toki paikantuvat kirjoitusajankohtaansa, mutta muisteltuja kokemuksia ei Seesmeren mukaan kertomuksissa yleensä kiinnitetä aikaan, joten hän tarkastelee eri aikojen erilaisten kokemusten sijaan yleistä saunakokemusta. Mainosaineisto taas on mahdollista ainakin osin ajoittaa tiettyihin vuosiin, ja se kuvastaakin selvemmin saunan representaatioiden muuttumista vuosikymmenien mittaan.

Vaikka nämä muutokset eivät ole Seesmeren tutkimuksen keskiössä, hän tarkastelee niitäkin erittelemällä erilaisten visuaalisten elementtien esiintymistä yhtäältä 1950-1980-lukujen ja toisaalta 1990-2010-lukujen mainoskuvissa. Analyysi tuo esiin kiinnostavia muutoksia esimerkiksi saunojien representoimisessa. 1990-lukua edeltävissäkin mainoksissa esiintyy ihmishahmoja, mutta yksin saunovia naisia ei niissä kuvata lainkaan, kun taas 2000-luvulle tultaessa suurin osa mainosten kuvista Seesmeren mukaan esittää yksinäistä naissaunojaa. Uudemmassa aineistossa saunojat - joita ei enää esitetä alastomina - ovat alkaneet näyttää nautiskelevilta ja itseensä keskittyneiltä: kiuasmainosten saunominen on muuttunut "miehekkäästä rehvastelusta naiselliseksi nautiskeluksi" (s. 206).

Tutkimuksen pääteemoista ensimmäisenä käsitellään maisemaa, joka toimii saunomiskokemuksen kehyksenä. Seesmerelle maisema on elettyjen paikkojen kimppu: konkreettisen ympäristön lisäksi se on mielenmaisemaa, ja siihen sisältyy saunomisen ja saunatilan stimuloimista muistoista sekä tilan menneeseen viittaavasta luonteesta muodostuva menneisyyden ulottuvuus. Paikka taas on saunan sisällä oleva tekemisen tila, johon aistiminen ja nykyhetki kytkeytyvät. Kokemuskertomuksissa saunomiseen liittyvä toiminta yhdistää saunojan maisemaan ja paikkaan, ja saunomisen jälkeen maisemaa havainnoidaan moniaistisesti - saunominen herkistää kokemaan ympäröivää luontoa. Kiuasmainoksissa paikka ja maisema ovat Seesmeren mukaan usein läsnä luonnonelementteinä, jotka edustavat aitoutta ja alkuperäisyyttä. Mainosten saunan maisemaa ovat kivet, tuli, höyry ja vesi.

Toinen käsitelty pääteema on kehollisuus. Saunasta kerrottaessa keho on läsnä aistien kautta; sauna koetaan esimerkiksi löylyn sihahduksina, savun hajuna, lämpönä ja kosteutena. Mainosaineistossa kehollisuus ilmenee saunojia esittävissä kuvissa, mutta myös teksteissä, jotka painottavat kehollista kokemusta rentoutumisesta, nautinnosta, lämmön tunteesta tai hengityksen helppoudesta. Saunaan liitetään kokemuskertomuksissakin monenlaisia hyvänolon tunteita, ja se voidaan myös kokea pyhänä.

Kolmas pääteema on ajallisuus tai menneisyys, joka on molemmissa aineistoissa läsnä useammalla tasolla. Lapsuutensa saunoja muistelemalla kertojat herättävät henkiin oman elämänhistoriansa, johon myös saunovia perheitä kuvaava mainosaineisto pyrkii vetoamaan. Menneisyys on myös myyttistä paratiisin aikaa tai kalevalaista aikaa - saunassa hikoillessaan saunoja voi päästä osaksi tästä tavoiteltavasta menneisyydestä. Varsinkin uudemmat kiuasmainokset vetoavat myyttiseen menneisyyteen esittäessään kiukaan välineenä, jonka kautta nykypäivän ihminen voi saavuttaa esivanhempiensa suhteen tuleen. Kolmantena menneisyyden tasona on kansallinen menneisyys: saunominen voidaan määritellä osaksi suomalaisena olemisen kokemusta. Menneisyyteen liittyy kaiho ja kaipaus, joka Seesmeren mukaan näkyy kokemuskerronnan nostalgisuudessa ja siinä, miten mainokset korostavat aitoutta. Mainonta tuo poissa olevan läsnä olevaksi esimerkiksi liittäessään moderniin sähkökiukaaseen savusaunamaisen löylyn merkityksiä. 
Seesmeri näkee saunan dikotomioita purkavana tilana, joka yhdistää menneisyyden ja tulevaisuuden, arjen ja pyhän, yhteisen ja yksityisen, luonnon ja kulttuurin, mielen ja ruumiin. Se herkistää aistimaan ulkoista todellisuutta mutta myös mielensisäisiä asioita. Paikkanakin sauna sijaitsee rajalla: pihapiirin ja metsän välimailla, rantaviivan tuntumassa tai talon kellarissa. Saunominen on tunnekokemuksena "kuin vierailu toisessa tai menneessä" (s. 246). Saunan välitilamaisuuden olennaisimmaksi muodoksi Seesmeri nostaa ajan rikkomisen: "Sauna on aikakone, jonka matkassa muistot ja aistit kietoutuvat yhteen." (S. 262.)

Tutkimuksen yhtenä tuloksena Seesmeri esittää lopuksi etnografisen pastissin käsitteen, jonka kautta hän tarkastelee henkilökohtaisen ja kulttuurisesti jaetun suhdetta. Pastissit ovat kokemuskertomusten ja mainosten tarjoamia tuokiokuvia, pikemminkin fragmentteja kuin kokonaisia tarinoita. Se, että kokemus ja kerronta eivät ole pelkästään henkilökohtaisia vaan kytkeytyvät myös jaettuun kulttuuriin, tekee pastisseista etnografisia. Seesmeren mukaan etnografiset pastissit välittävät saunomisen kehollista kulttuuriperintöä ja toimivat kulkuneuvoina omista havainnoista kulttuurisiin malleihin tai toisin päin. Ne sisältävät jännitteen läsnä olevan ja kuvitellun välillä, tiivistävät kokemuksia ja suhteuttavat mennyttä nykyaikaan.

\section{Yhteiseksi tulkittu kokemus}

Laura Seesmeri on perehtynyt saunomiseen proseminaarityöstään lähtien, ja yli kahdenkymmenen vuoden kokemus aiheesta näkyy väitöstutkimuksen teemojen laajuutena ja niiden käsittelyn syvyytenä. Se lienee myös muovannut tutkijan esiymmärrystä, joka väitöskirjassa vahvasti painottuu; esimerkiksi menneisyyden aikatason kytkeytyminen saunomiseen sisältyy jo tutkimuksen ennakko-oletuksiin. Toisinaan tuntuu hankalalta erottaa esiymmärrystä tutkimuksen tuloksista, vaikka Seesmeri sivuilla 47-48 eksplikoikin niitä oletuksia, jotka ovat ohjanneet aineiston tulkintaa. Saunomisen merkityksiä tuodaan esiin jo analyysilukuja edeltävässä osuudessa (esim. s. 51), jolloin lukijalle jää epäselväksi, onko kyse tutkimustuloksista. Analyysiluvuissa tiedon muodostumisen prosessi on kuitenkin monin paikoin seurattavissa: mukana on runsaasti aineistokatkelmia, joita tekstissä oivaltavasti analysoidaan.

Tekijän sauna-aiheisista keruista koostama sitaattiaineisto kertoo erityisesti 1920-1940luvuilla syntyneiden, usein maalta kaupunkiin muuttaneiden saunakokemuksista. Keruukonteksti on vaikuttanut siihen, miten saunomiskokemuksista kerrotaan, ja aineistositaattien valintaa on ohjannut tutkijan kiinnostus saunaan nimenomaan menneisyyden kokemisen paikkana. Käytetty aineisto on siis monin tavoin valikoitunutta, mikä tutkimuksessa tuodaankin ansiokkaasti esiin. Tutkimustuloksia esitettäessä aineiston painotukset ja sen mahdollinen heterogeenisuus kuitenkin tuntuvat katoavan. Seesmeren konstruoima sauna toimii menneisyyttä ja maisemaa kehon kautta yhdistävänä ja tietynlaisia aistikokemuksia tuottavana paikkana riippumatta siitä, kuka saunoja on tai missä, milloin ja miten hän saunoo. Saunomisen sosiaaliset ulottuvuudet jäävät taustalle, kun tutkimus piirtää kuvaa aistihavaintoihinsa keskittyneestä, maiseman ja menneisyyden kokemiseen herkistyneestä saunojasta.

Tutkimuksen alkupuolella Seesmeri toteaa esittävänsä yhden tulkinnan saunasta, "kaikki voisi olla toisinkin" (s. 62), ja loppuyhteenvedossa hän viittaa lyhyesti toisenlaisen saunomiskokemuksen mahdollisuuteen: "En väitä, etteikö olisi mahdollista saunoa irrallaan tästä kaikesta". Kuitenkin saunoja voi hänen mukaansa aina halutessaan saavuttaa kokemuksen, 
"jossa mennyt ja nykyinen, yksilöllinen ja yhteisöllinen limittyvät toisiinsa", ja niinpä on mahdollista "saunoa itselleen menneisyys". (S. 265.) Väitöskirja tuottaa siis käsitystä kaikille saunojille yhteisestä kokemuksellisuudesta.

Teoksen kieli on käsitteistä tiheää, ilmaisu on usein raskaslukuista ja kieliasu hieman viimeistelemätön. Poeettisiakin sävyjä saava, paikoitellen hiukan jäsentymätön tutkimusteksti saattaa jäädä lukijalle vaikeasti hahmotettavaksi; ilmaisun selkeyttäminen sekä tekstin rönsyjen ja toistojen karsiminen olisivat voineet tehdä tutkimuksesta helpommin lähestyttävän. Teos kuitenkin myös palkitsee lukijansa. Rikas, moneen suuntaan avautuva väitöskirja tarjoaa paljon tarkkanäköisiä havaintoja ja tulkintoja, jotka syväluotaavat kehollisuuden, ajallisuuden, paikan ja maiseman teemoja kiehtovalla tavalla.

\section{Kirjallisuus}

Edelsward, Lisa M. 1991. Sauna as Symbol: Society and Culture in Finland. New York: Peter Lang.

Frykman, Jonas. 2004. "I hetluften: Svensk bastu som ideologi och praktik." Teoksessa Tio tvättar sig, toimittanut Christina Westergren, 86-107. Stockholm: Nordiska museet.

Wiell, Karolina. 2018. Bad mot Lort och Sjukdom: Den privathygieniska utvecklingen i Sverige 1880-1949. Uppsala: Uppsala universitet.

FT Nika Potinkara työskentelee tällä hetkellä vierailevana tutkijana Uppsalan yliopistossa. Hänen tutkimuksensa käsittelee Ruotsin suomalaistaustaisten väestöryhmien asemasta käytyä keskustelua ja kansallisen vähemmistön statukseen liittyviä kamppailuja. 